\title{
Лексика традиционных послесвадебных обрядов в тувинском языке
}

\author{
Любовь С. Кара-оол \\ Тувинский государственный университет, Российская Федерация
}

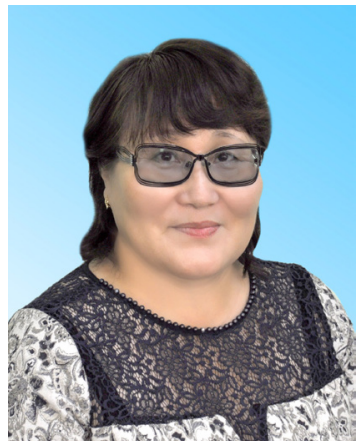

В статье представлен обзор лексики послесвадебных обрядов в тувинском языке с описанием этнографического своеобразия обрядов. Такой подход оправдан в связи с тем, что фразеологически связанное значение лексемы или фразеосочетания свабедной обрядности понимается правильно, без искажения. Материалом исследования послужили сведения из опубликованных работ, словарей, а также данные экспедиций автора по ареальным зонам тувинского языка в 1999-2015 г2.

Анализ лексики традиционного послесвадебного обряда позволил выявить следующие особенности: а) наименования и фразеосочетания традиционных послесвадебных обрядов в основной своей массе являются собственно тувинскими устойчивыми сочетаниями с общетюркскими компонентами (2 лексемы и 6 фразеосочетаний); б) в корпусе названий традиционных послесвадебных обрядов встречаются также собственно тувинские фразеосочетания из общетюркских основ и монгольских заимствований (4), подтверждающие тот факт, что на протяжении длительного времени тувинцы жили в тесном контакте смонголами; в) значительная часть фразеосочетаний зафиксированы в речи носителей зарубежных говоров тувинского языка - ховдинского, цэнгэлского, цагаан-нуурского, а также эрзинского говора юго-восточного диалекта, монгун-тайгинского, кара-холского, бай-тайгинского говоров западного диалекта и хондергейского говора ценнтрального диалекта; г) только 4 фразеосочетания и 1 одна лексема вошли в состав общеупотребительных; д) анализируемые примеры показывают лексические, фонетические диалектные особенности речи носителей юго-восточного, западного, центрального диалектов и зарубежных говоров тувинского языка; е) с течением времени значения некоторых слов, связанных с послесвадебными обрядами подверглись сужению или расширению.

Ключевые слова: свадебный обряд; свадьба; тувинский язык; тувинцы; фразеологизм; фразеосочетание; общетюркский; монголизм

Статья написана при финансовой поддержке РФФИ в рамках научного проекта гранта № 19-012-00073

«Трансформационные процессы в ономастике народов Центральной Азии: история и современность (на примере Тувы,

тофаларии, Калмыкии и Монголии».

\section{Для цичтирования:}

Кара-оол Л. С. Лексика традиционных послесвадебных обрядов в тувинском языке // Новые исследования Тувы. 2020, № 4. C. 169-179. DOI: www.doi.org/10.25178/nit.2020.4.12

\footnotetext{
Кара-оол Любовь Салчаковна - кандидат филологических наук, доцент кафедры теории и методики языкового образования и логопедии Тувинского государственного университета. Адрес: 667000, Россия, г. Кызыл, ул. Ленина, д. 36. Тел.: +7 (923) 549-02-64. Эл. адрес: 1karaool61@mail.ru
}

KARA-OOL, Lyubov Salchakovna, Candidate of Philology, Associate Professor, Chair of Theory and Methods of Language Education and Speech Therapy, Tuvan State University. Postal address: 36, Lenina Str., 667000, Kyzyl, Russia. Tel.: +7 (923) 549-02-64. E-mail: lkaraool61@mail.ru 


\title{
Traditional post-wedding ceremonial vocabulary in Tuvan language \\ Article
}

\author{
Lyubov S. Kara-ool \\ Tuvan State University, Russian Federation
}

\begin{abstract}
The article presents an overview of post-wedding ceremonial vocabulary in Tuvan language and in the descriptions of ethnography of these rites. This approach relies on the fact the phraseological meaning of the lexeme or of the phraseological collocation of wedding rites is understood correctly, without distortion. Our study is based on materials from published works, dictionaries, as well as on data obtained during the author's expeditions to the areal zones of the Tuvan language in 1999-2015. Studying traditional post-wedding ceremonial vocabulary has revealed the following: a) the names and phraseological units of traditional post-wedding rites are mostly Tuvan collocations with common Turkic components (2 lexemes and 6 collocations); b) in the corpus of traditional post-wedding ritual names there are also native Tuvan collocations of common Turkic bases and Mongolian borrowings (4), proving that Tuvans had been living in close contact with the Mongols for a long time; c) a significant part of collocations has been found present in the speech of native speakers of foreign Tuvan dialects - Khovd, Tsengel, Tsagaan-nuur, as well as the Erzin variant of the South-Eastern dialect, Mongun-taiga, Kara-khol and Bai-taiga variants of the Western dialect, as well as the Khondergey variant of the Central dialect; $d$ ) only 4 collocations and 1 lexeme are now used commonly; e) the analyzed examples show lexical and phonetic dialect features of the language of native speakers of the SouthEastern, Western, Central and foreign dialects of the Tuvan language; $f$ ) meanings of some post-wedding ritual words have been narrowed or expanded over time.
\end{abstract}

Keywords: wedding ceremony; wedding; Tuvan language; Tuvans; phraseological unit; collocation; common Turkic; Mongolianism

\section{Financing}

The article was written with the support of RFBR as part of grant project No. 19-012-00073 "Transformative processes

in the onomastics of the languages of Central Asia: history and modernity in the cases of Tuva, Tofalaria, Kalmykia and Mongolia".

\author{
For citation: \\ Kara-ool L. S. Leksika traditsionnykh poslesvadebnykh obriadov $\mathrm{v}$ tuvinskom iazyke [Traditional post-wedding \\ ceremonial vocabulary in Tuvan language]. New Research of Tuva, 2020, no. 4, pp. 169-179. (In Russ.). DOI: www.doi.
} org/10.25178/nit.2020.4.12

\section{Введение}

Лексика послесвадебного обряда отражает не только особенности материальной, культурной и духовной культуры тувинского народа, но и лексические и фонетические особенности тувинского языка. Изучение ее сопряжено с некоторыми трудностями, в частности, с недостаточностью фактического материала: в советское время традиционные семейные обряды и обычаи были под запретом, поскольку считались пережитками прошлого, поэтому среди информаторов старшего поколения осталось мало знатоков, хорошо помнящих традиционные свадебные обряды. В исследованиях, связанных с данной темой, также наблюдаются расхождения в описании свадебных обрядов. Интерпретации семантики некоторых слов и устойчивых словосочетаний являются спорными.

Главная цель статьи - последовательный анализ лексики послесвадебного обряда в тувинском языке на основе материалов автора, собранных во время комплексных и диалектологических экспедиций по ареальным зонам тувинского языка (1999-2015 гг.) - все кожууны Республика Тыва (за исключением Тере-Холского), Ховдский, Цэнгелский и Цагаан-Нуурские аймаки Монголии, где компактно проживают этнические тувинцы, а также научной литературы, в которой содержатся рассматриваемые лексемы. Обзор лексики сопровождается описанием этнографического своеобразия обрядов. Такой подход оправдан в связи с тем, что фразеологически связанное значение лексемы или фразеосочетания свабедной обрядности понимается правильно, без искажения. 


\section{Из истории изучения лексики традиционных свадебных обрядов}

Обзор литературы по лексике традиционных свадебных обрядов в тувинском языке нами сделан в предыдущей статье «Лексика предсвадебных обрядов в тувинском языке» (Кара-оол, 2015: 17-31), поэтому в данной работе даем в сжатом варианте.

Первые этнографические и лингвистические сведения о тувинских свадебных обрядах, связаны с работами Е. К. Яковлева (Яковлев, 1900), Г. Е. Грумм-Гржимайло (Грумм-Гржимайло, 1926), Ф. Я. Кона (Кон, 1934), которые помимо основных задач своих экспедиций, изучали также быт, традиции и обычаи местного населения. В своих работах они описали отдельные разрозненные элементы свадебного обряда и всего, что с ним связано, но, к сожалению, лексика свадебного обряда в значительной степени была зафиксирована в искаженном варианте, что объясняется с незнанием исследователями местного языка. С середины XX столетия свадебные ритуалы тувинцев нашли отражение в исследованиях С. И. Вайнштейна (Вайнштен, 1961: 135-141), Л. П. Потапова (Потапов, 1969: 228-278). Если первого автора интересовали вопросы брачно-семейных отношений, то второй, подробно описывая этнографию тувинцев, изучил и свадебный обряд родоплеменных групп, которые проживали на территории Монгун-Тайги и Кара-Холя, относящихся к западному диалекту (ЗД), СутХоля - центральный диалект (ЦД) и Эрзина - юго-восточный диалект (Ю-ВД) (там же: 228-278).

В советское время свадебный обряд, как важный элемент культуры тувинцев, стал объектом исследования и тувинских ученых, например, С. М. Биче-оол. В ее диссертационной работе (Бичеоол, 1974) анализируются истоки традиционных форм брака и семьи, брачные обряды тувинцев, а также изменения, произошедшие в традиционных брачно-семейных отношениях в ходе культурной революции в периоды Тувинской Народной Республики и Тувинской АССР. С. М. Биче-оол, изучив пережиточные явления матрилокального брака, свидетельствующих о силе традиций, отметила, что тувинская семья прошла путь от древних дуально-родовых, экзогамных норм до патрилокальных брачных отношений (там же: 6-8).

Истинный знаток тувинской этнографии М. Б. Кенин-Лопсан (Кенин-Лопсан, 1994: 24-35; 2006: 22-33), описывая в своих книгах тувинские свадебные обряды, зафиксировал большой объем лексики, и, как носитель языка, дал их в правильных формах. Т. Кушкаш, исследуя древние традиции Тоджи, кратко описала свадебный обряд таежных и речных тоджинцев (Кушкаш, 1996: 23-24). Этические нормы и поведенческие аспекты свадебных обрядов тувинцев исследовала С. Ч. Донгак (Донгак, 2012), в ее научно-популярном издании рассматриваются также проблемы нарушения некоторых этических норм современных свадебных обрядов.

Свадебные обряды этнических тувинцев Монголии, проживающих в аймаках Цэнгэл, Ховд и Цагаан-Нуур, описали П. С. Серен (Серен, 2000: 26-32; 2006: 50-68; 2013a: 22-34; 2013b: 44-51), Ц. Уламсуренгийн (Уламсуренгийн, 2003: 12-17) и Е. В. Айыжы (Айыжы, 2005). Они отметили хорошую сохранность данных обрядов. А вопросы межэтнических браков тувинцев Монголии и Китая изучила М. В. Монгуш (Монгуш, 2002: 88-94). Ч. К. Ламажаа и Ш. Б. Майны анализируют социокультурные функции свадебной обрядности тувинцев как фактора, определяющего и отражающего традиции социальных связей в этнической общности (Ламажаа, Майны, 2020).

В лингвистике лексика традиционного свадебного обряда тувинцев не освещена полностью, хотя есть исследования, в том числе автора данной статьи (Кара-оол, 2007: 99-101; 2008: 443-456; 2015: 17-31; Хертек, 2007: 68-72; 2008: 80-91). В рассмотренных работах свадебная лексика зафиксирована отрывочно, что связано с основной целью и задачами авторов, в описании этапов свадебного обряда и семантики некоторых лексем и фразеосочетаний встречаются расхождения (Кара-оол, 2015: 18).

Традиционный свадебный обряд любого народа - «это своеобразная народная пьеса со многими картинами и действующими лицами» (Карпухин, 2011: 3), которую можно условно разделить на три акта. Соответственно и свадебная лексика делится на три группы: лексика предсвадебных обрядов ‘куда мурнунда ёзулалдар лексиказы'; лексика свадебных обрядов 'куда ёзулалдар лексиказы' и лексика послесвадебных обрядов 'куда соонда ёзулалдар лексиказы'.

Лексика традиционного предсвадебного обряда тувинцев еще не исследовалась. Отдельные ее элементы нашли свое отражение в работах о свадебном обряде (Серен, 2000), о символике мифологических образов в обрядах (Хертек, 2007: 68-72) и терминологии свадебной обрядности (Хертек, 2008: 8091). Автор статьи тоже включала их в работы, связанные с лексикой свадебного обряда (Кара-оол, 2007), с тувинской семьей (Кара-оол, 2008). Но затем, собрав значительный языковой материал, написала статью по лексике предсвадебных обрядов (Кара-оол, 2015: 17-31). Лингвистическое исследование лексики досвадебных обрядов проведено через описание их этнографического своеобразия и с учетом 
территориально-диалектных особенностей тувинского языка. В связи с этим выявились особенности употребления лексики досвадебной обрядности носителями центрального, юго-восточного и северовосточного диалектов, а также носителями зарубежных диалектов - ховдинского и цэнгелского. В данной работе автор определил и расхождения в традиционных предсвадебных обрядах тувинцев разных мест.

Тувинские свадебные обряды, как и у других народов, не завершаются со свадьбой. И в этой свадебной картине можно выделить несколько послесвадебных обрядов куда соонда ёзулалдар - букв. ‘обряды после свадьбы’:

- арнын чазар - обряд признания невестки старшими родственниками мужа и снятие запрета общения невестки со свекром и со старшими родственниками мужа;

- эмиг карыжы - обряд подношения подарка сватье;

- аалдаашкын - первая поездка молодоженов к родственникам невестки;

- аал-кодан ээрени кылдыртыр - изготовление амулета молодой семьи, который будет охранять членов семьи и всего, что находится на территории аала: скот, имущество.

Итак, в основной части статьи перейдем к анализу каждого из указанных обрядов, определив лексическое значение фразеосочетания, уточнив этимологию его компонентов, а также дав краткое описание обряда, чтобы более точно передать фразеологически связанное значение лексемы или фразеосочетания предсвабедной обрядности.

\section{Арнын чазар}

Арнын чазар букв. - ‘лицо (ее) открывать' (Хертек, 1975: 42) - первый послесвадебный обряд - обряд признания невестки старшими родственниками мужа и снятие запрета общения невестки со свекром и со старшими родственниками мужа. По Я. Ш. Хертеку, имеет также значение 'ближе знакомить друг с другом (преимущественно будущих молодожёнов)' (там же).

Собственно тувинский фразеологизм арнын чазар состоит из общетюркских основ: арнын (ее, его) арын - ‘лицо', 'страница', грам. 'лицо' (Тувинско-русский словарь, 1968: 72), см. алын / алин - ‘лоб, чело', 'перед’, ‘лицо, физиономия, внешний вид', 'склон горы' (Севортян, 1974: 146);

чазар / час - 'разворачивать, открывать', 'распечатывать, распаковывать' (Тувинско-русский словарь, 1968: 510), др.-тюрк. jaz- -'развязывать', 'распускать', 'распускаться, растекаться’ (Древнетюркский словарь, 1969: 250), см. тоф. час - 'разбирать на части’ (Рассадин, 1971: 194).

Наравне с рассмотренным фразеологизмом обряд признания невестки старшими родственниками мужа обозначается следующими фразеосочетаниями:

1) арнын ажыдар букв. - 'лицо открывать' (Кон, 1934: 88; Донгак, 2012: 24).

Собственно тувинское фразеосочетание арнын ажыдар состоит из общетюркских основ: арнын ‘(ее) лицо’, см. выше;

ажыдар (аъжыдар) / ажыт- в прям. и перен. - 'открывать, раскрывать', 'отворять', 'растворять' и подобное (Тувинско-русский словарь, 1968: 41; Толковый словарь ..., 2003: 74), каузатив от ащ- см. ач- во всех источниках 'открывать' (Севортян, 1974: 209);

2) алганып бээр букв. ‘благословлять' (монгун-тайгинский говор ЗД) (Потапов, 1969: 242).

Собственно тувинское фразеосочетание алганып бээр состоит из общетюркских основ: алганып / алганыр (аълганыр) рел. - 'выкрикивать заклинания (о шамане)' (Тувинско-русский словарь, 1968: 53), 'камлать, шаманить, напевая текст’ (Толковый словарь ..., 2003: 109), см. *алқа- - ‘благословлять' (Древнетюркский словарь, 1969: 38), алқа-/ алға- - 'благословлять', 'восхвалять' (Севортян, 1974: 137-138; Татаринцев, 2000: 98-99);

бээр / бер- - ‘давать, выдавать', ‘подавать' (Тувинско-русский словарь, 1968: 132), *ber- прям. и перен. 'давать, вручать', 'даровать' (Древнетюркский словарь, 1969: 95), см. бе:p- - 'давать' (Севортян, 1978: 114; Татаринцев, 2000: 214; Сравнительно-историческая грамматика ..., 2001: 700), как вспомогательный глагол указывает на действие совершаемое для другого лица (Тувинско-русский словарь, 1968: 132);

3) алгыш (аългыш) 'благословление' (кара-хольский говор ЗД) (Потапов, 1969: 253), уст. ‘благословление', 'напутствие' (Тувинско-русский словарь, 1968: 53) - имя производное от общетюркского алқа-/ алға- - ‘благословлять’ (Севортян, 1974: 137-138; Татаринцев, 2000: 101). 

31).

4) келин алгадыр букв. - 'невестку благословлять' (хондергейский говор ЦД) (Кенин-Лопсан, 1994:

Собственно тувинское фразеосочетание келин алгадыр состоит из общетюркских основ: келин 'невестка' встречается во всех тюркских языках, этимологизируется на тюркской почве, как имя на -н от глагола кел 'приходить' (Севортян, 1980: 17; Сравнительно-историческая грамматика ..., 2001: 302; Кара-оол, 2006: 126);

алгадыр (аългадыр) - ‘благословлять', 'напутствовать' (Тувинско-русский словарь, 1968: 53), 'высказывать благопожелания’ (Толковый словарь ..., 2003: 109), см. *алқа - ‘благословлять’ (Древнетюркский словарь, 1969: 38; Севортян, 1974: 137; Татаринцев, 2000: 98).

5) кенин сойгалаар букв. - 'невестку снимать' (цэнгэлский говор Монголии) (Серен, 2006: 65), т. е. признание невестки старшими родственниками мужа.

Собственно тувинское фразеосочетание состоит из общетюркских основ: диал. кенин - 'невестку' (нарынский говор Ю-ВД) (Полевые материалы автора, 1999), диалектное кен является стяженной формой от общетюркского келин (Сравнительно-историческая грамматика ..., 2001: 302);

сойгалаар / сойгала - 'сдирать (кору)', перен. - 'разоблачать' (Тувинско-русский словарь, 1968: 380); в переносном значении 'снять (с невестки) запрет (общения со свёкром)' - не зафиксировано в словаре, дериват от общетюркского сой- - 'снимать', 'сдирать' (шкуру), 'раздеть, снять' (Древнетюркский словарь, 1969: 507; Этимологический словарь ..., 2003: 283-285);

6) хол алчыр букв. - 'руку передавать (друг другу)' - ‘из рук в руки передавать', т. е. свободно общаться со свёкром и другими родственниками мужа (цэнгэлский говор Монголии) (Серен, 2006: 65; Полевые материалы автора, 2008).

Собственно тувинское фразеосочетание состоит из общетюркских основ: хол - 'рука/ручной', 'передняя нога' (Тувинско-русский словарь, 1968: 480), см. " $k o l$ - 'рука', 'почерк, подпись', 'ответвление' (Сравнительно-историческая грамматика ..., 2001: 244-245; Этимологический словарь ..., 2000: 37-43);

алчыр совм.-взаимн. - ‘брать вместе’, ‘брать друг у друга’ (Тувинско-русский словарь, 1968: 56) / алыш- от общетюркского ал- - ‘брать’ (Севортян, 1974: 127; Татаринцев, 2000: 87; Сравнительноисторическая грамматика ..., 2001: 699): алчыр в переносном значении - 'свободно общаться’.

Дадим краткое описание обряда: на этапе введения невестки в род жениха появлялся персонаж Аскак-Кадай (Хертек, 2007: 70) букв. 'хромая старуха' с благородной миссией. Обычно выбирали благополучную женщину болумчалыг кадай из рода или окружения, которая, разбрасывая просо из мешка и ударяя топором по земле, обходила ближние аалы и приводила невестку в юрту свёкра и свекрови (Кенин-Лопсан, 1994: 31). По некоторым сведениям, в роли Аскак-Кадай выступал дядя невестки по матери даай с головным убором невестки (Полевые материалы автора, 2008).

Невестка, зайдя в юрту родителей мужа, садилась рядом с женщинами и кланялась очагу юрты свёкра и свекрови одунга мөгеер, бросая в горящий огонь щепку с веточками можжевельника артыш (Потапов, 1969: 261). Свекровь кунчуг с благожеланиями преподносила невестке пиалу с молоком, и та пригубив, возвращала свекрови - ритуал символизировал сближение свекрови и невестки. Затем начинался обряд благословления невестки (Кенин-Лопсан, 1994: 31). Свекор с благопожеланиями подходил к невестке, снимал с нее думаалай - 'свадебное головное покрывало' и надевал на ее голову национальную шапку. Затем мужчины по очереди угощали невестку нюхательным табаком чыттаар таакпы. После чего она выходила из юрты и угощала молоком родственников мужа, которые сидели у юрты, начиная со старших. Затем снова входила в юрту, кропила молоко в огонь, выпрашивая семейного счастья и благополучия.

Арнын чазар - это не просто акт «открывания» лица невесты, но и утверждения ее в новом статусе. Теперь она член рода жениха, и с этого дня может разговаривать со свекром и со старшими родственниками мужа, находиться с ними в одном помещении, передавать что-либо из рук в руки.

\section{Эмиг карыжы}

Эмиг карыжы букв. 'возмещение груди', т. е. подношение подарка сватье (Рукописный фонд Тувинского научно-исследовательского института языка, литературы и истории (ТНИИЯЛИ) № 108, тетрадь 6. Историко-этнографические материалы, собранные экспедицией сектора истории ТНИИЯлИ 11.02-20.02. 958 г. в Чаа-Хольском районе. Руководитель группы Л. В. Гребнев; Потапов, 1969: 243, 255; Кара-оол, 2007: 100; 2008: 455). 
Собственно тувинское фразеосочетание состоит из общетюркских основ:

эмиг - 'грудь', 'вымя' (Тувинско-русский словарь, 1968: 613), дериват от эм- - 'сосать', 'впитывать', 'есть, кормиться' (Севортян, 1974: 271) + -иг древнейший аффикс, сохранившийся в числе немногих живых тюркских словообразовательных аффиксов (Исхаков, Пальмбах, 1961: 151), см. *еmig - 'грудь женщины, соски', 'соски животных’ (Древнетюркский словарь, 1969: 173);

карыжы - 'возмещение', т. е. 'невестку, принятую в род жениха, “возмещали” дойной коровой'. Данное значение не отмечено в тувинских словарях, ср. карышкак перен. 'пересекающийся’ (Тувинскорусский словарь, 1968: 231), т. е. ‘в обмен’; др.-тюрк. qarï̌- - ‘встречаться’, ‘сходиться’ (Древнетюрский словарь, 1969: 428), см. тоф. һарышқақ - 'пересекающийся’, 'перекрещивающийся’ (Рассадин, 1995: 38, 207), сойот. Һарышқақ - ‘пересекающийся’, ‘перекрещивающийся’ (Rassadin, 2010: 127).

Дадим краткое описание обряда: после обряда признания невестки свёкром и старшими родственниками проводился обряд эмиг карыжы, когда отец жениха дарил матери невестки дойную корову или лошадь белой масти: за молоко матери, которым была выкормлена дочь (Потапов, 1969: 243). Есть и другое объяснение: невестка как бы «уходила» из своего рода, став членом рода мужа, и ее «возмещали» дойной коровой в благодарность за невестку (Полевые материалы автора, 2010).

\section{Аалдаашкын}

Аалдаашкын - 'приезд в гости' (Кенин-Лопсан, 1994: 33; Кара-оол, 2008: 455) / аалдаар - 'гостить' (цагаан-нуурский говор Монголии) (Полевые материалы автора, 2015) - первая поездка молодоженов к родственникам невестки.

Собственно тувинское слово с общетюркской основой аалдаашкын - 'приход (приезд) в гости', 'посещение', перен. 'нападение, разбой’ (Толковый словарь ..., 2003: 37) > аалда- - 'гостить' (Тувинскорусский словарь, 1968: 28) > аал - 'селение', 'табор', 'двор' (там же: 27), см. а:ғыл, - 'селение', 'дом’ (Севортян, 1974: 83; Татаринцев, 2000: 35).

Наряду с общепринятым аалдаашкын существуют и другие выражения:

1) өнчүзүн алыр букв. 'наследство взять' (эрзинский говор Ю-ВД) (Потапов, 1969: 265).

Собственно тувинское фразеосочетание состоит из монголизма өнчүзүн (имущество (ее)) / өнчү - 'собственность', 'имущество', 'владение' (Тувинско-русский словарь, 1968: 336), см. өмч - 'собственность', 'личное имущество', 'наследство' (Большой академический ..., 2001с: 22; Сравнительно-историческая грамматика ..., 2001: 348; Татаринцев, 2008: 388) и общетюркского алыр см. выше ал- - ‘брать'.

На өнчүзұн алыр невестка приезжала за своим имуществом, которое приумножалось с раннего детства: ей дарили домашних животных при наречении именем, во время первой стрижки волос в 3 года и т. д.;

2) көгээржик аксы букв. - ‘крышка кожаной фляжки’ (бай-тайгинский говор 3Д) (Хертек, 2008: 90).

Собственно тувинский изафет көгээржик аксы состоит из монголизма көгээржик - 'кожаная фляжка' (для кумыса или араки) (Тувинско-русский словарь, 1968: 256): көгээр - ‘большая кожаная фляга’ (для кумыса или араки) (там же) + умен.-ласк. аф. -жик (Исхаков, Пальмбах, 1961: 148), см. п.-монг. хөхүүр 'бурдюк для вина' (Большой академический ..., 2002: 151);

общетюркского аксы - 'устье (реки)', 'дуло', 'жерло', 'крышка', 'устный’ (Тувинско-русский словарь, 1968: 30), см. *агыс - 'рот, уста; речь, разговор; отверстие; вход’ (Севортян, 1974: 81-82; Татаринцев, 2000: 41-42).

Көгээржик аксы - «так называется скот, выделяемый молодым со стороны родственников жены, когда они приезжают к ним погостить через год после свадьбы» (Хертек, 2008: 90). Метафорическое выражение: по тувинскому обычаю посуду не возвращают пустой, поэтому, когда молодые собирались домой, вместе с когержиком отдавали и личный скот девушки, который приумножался с детства, а также были подарены в день свадьбы.

Дадим краткое описание обряда: примерно через месяц или год (в материалах разные сведения) молодые, вместе с замужней сестрой невестки, ездили в гости к ее родителям. Молодые приезжали с подарками, угощениями и аракой (молочное вино) в когержике. А когда молодые собирались обратно, им выделяли скот, который принадлежал невестке и был подарен в день свадьбы. 
Родители, выделив дочери скот, выводила ее из-под своей опеки. А она, внеся во вновь организовавшее хозяйство часть скота, домашнюю утварь, а в некоторых районах и юрту, оставалась собственницей своего имущества, что давало ей равное право в управлении хозяйством.

\section{Аал-кодан ээрени кылдыртыр}

Аал-кодан ээрени кылдыртыр букв. - ‘селения идол делать' (Куулар и др., 2014: 46-47), т. е. изготовить амулет молодой семьи, который будет охранять членов семьи и все, что находится на территории аала: скот, имущество и т. д. У Л. П. Потапова зафиксировано как приобретение новых ээренов (Потапов, 1969: 243).

Собственно тувинское устойчивое фразеосочетание аал-кодан ээрени кылдырттыр состоит из общетюркских основ и монголизма: аал-кодан - 'территория аала', т. е. селения (Тувинско-русский словарь, 1968: 27), см. а:ғыл - ‘селение’, ‘дом’ (Севортян, 1974: 83; Татаринцев, 2000: 35); монголизм кодан - ‘место, где находится аал (юрта или юрты, а также расположенный рядом скотный двор)’, см. п.-монг. qotan - ‘стена, вал, ограда, город, селение, стойбище’ (Татаринцев, 2004: 168);

общетюркское ээрени (ее, его, их) ээрен уст. - ‘идол’ (шаманский) (Тувинско-русский словарь, 1968: 623) зафиксировано в тюркских языках Сибири, см. тофаларское ‘шаманский идол, амулет’ (Рассадин, 1971: 184), сойот. ээрән - ‘шаманский амулет’ (Rassadin, 2010: 229), в современном тувинском языке ээрен - общеупотребительное слово;

общетюркское кылдырттыр - ‘заставлять (просить) делать что-л.' (Тувинско-русский словарь, 1968 : 276), дериват кыл- - ‘делать’ во всех источниках (Этимологический словарь ..., 2000: 205).

Дадим краткое описание обряда: завершающий торжественный обряд, который дает повод молодым собрать у себя родственников спустя два или три месяца после свадьбы. Молодожёны приглашали шамана для изготовления амулета семьи аал-кодан ээреннери кылдыртыр и первого моления-угощения ээреннер чемгерер (Куулар и др., 2014: 46-47).

Шаман, изготовив аал-кодан ээреннери, совершал обряд угощения новых ээренов. Всё это сопровождалось исполнением шаманских алгышей хамның алгыжы, а затем вешал их на почетном месте юрты. Снимали их только через 3 дня, складывали с ээреном, привезённым невесткой из родительского дома, т. е. амы-хууда ээрен - ‘личный амулет’, убирали в сундук. Пользовались ими, если кто-то из семьи жаловался на свое здоровье или перед родами молодой хозяйки: доставали ээрены из хранилища, развешивали над постелью человека, окуривали можжевельником. А после выздоровления больного или благополучных родов невестки убирали в сундук.

\section{Заключение}

Анализ лексики традиционного послесвадебного обряда позволил выявить следующие особенности: а) наименования и фразеосочетания традиционных послесвадебных обрядов в основной своей массе являются собственно тувинскими устойчивыми сочетаниями с общетюркскими компонентами (2 лексемы и 6 фразеосочетаний); б) в корпусе названий традиционных послесвадебных обрядов встречаются также собственно тувинские фразеосочетания из общетюркских основ и монгольских заимствований (4), подтверждающие тот факт, что на протяжении длительного времени тувинцы жили в тесном контакте с монголами; в) значительная часть фразеосочетаний зафиксированы в речи носителей зарубежных говоров тувинского языка - ховдинского, цэнгэлского, цагаан-нуурского, а также эрзинского говора из юго-восточного диалекта, монгун-тайгинского, кара-холского и байтайгинского говоров из западного диалекта, а также хондергейского говора из центрального диалекта; г) только 4 фразеосочетания и 1 одна лексема вошли в состав общеупотребительных; д) анализируемые примеры показывают лексические, фонетические диалектные особенности речи носителей юговосточного, западного центрального диалектов и в зарубежных говоров тувинского языка; е) с течением времени значения некоторых слов, связанных с послесвадебными обрядами подверглись сужению или расширению.

Лексика традиционных послесвадебных обрядов тувинцев показывает символичность обрядов, которые проводились при стечении близких и дальних родственников. И основные элементы традиционных послесвадебных обрядов соблюдаются и сегодня, несмотря на то, что они видоизменялись под воздействием самых разных фактов. 


\section{СПИСОК ЛИТЕРАТУРЫ}

Айыжы, Е. В (2005) Свадебная обрядность тувинцев Кобдоского аймака Монголии // Природные условия, истории и культуры Западной Монголии и сопредельных регионов: материалы VII Международной конференции (19-23 сентября 2005 г. г. Кызыл): в 2 т. / В. И. Лебедев, С. О. Ондар, Ю. Г. Полулях. Кызыл : ТувИКОПР СО РАН. Т. 2. 252 с. С. $16-20$.

Биче-оол, С. М. (1974) Традиционные брачно-семейные отношения у тувинцев и их изменения в связи с социалистическими преобразованиями в Туве: автореферат дисс... канд. ист. наук. Л. 20 с.

Большой академический монгольско-русский словарь (2001a) / отв. ред. Г. Ц. Пюрбеев. М. : ACADEMIA. Т. I. A-Г. 520 c.

Большой академический монгольско-русский словарь (2001b) / отв. ред. Г. Ц. Пюрбеев. М. : ACADEMIA. Т. II. Д-О. $514 \mathrm{c}$.

Большой академический монгольско-русский словарь (2001с) / отв. ред. Г. Ц. Пюрбеев. М. : ACADEMIA. T. III. Ө-Ф. 440 c.

Большой академический монгольско-русский словарь (2002) / отв. ред. Г. Ц. Пюрбеев. М. : ACADEMIA. T. IV. X-Я. 510 c.

Вайнштейн, С. И. (1961) Тувинцы-тоджинцы. М. : Наука. 222 с.

Грумм-Гржимайло, Г. Е. (1926) Западная Монголия и Урянхайский край : в 3 т. Л. : б. и. Т. 3. Антропологический и этнографический очерк этих стран. 415 с.

Донгак, С. Ч. (2012) Тыва куда ёзулалдары = Традиции тувинской свадьбы. Кызыл : Изд-во ТувГУ. 72 с. (На тув. и рус. яз.)

Древнетюркский словарь (1969) / ред. В. М. Наделяев, Д. М. Насилов, Э. Р. Тенишев, А. М. Щербак. Л. : Наука. 676 с.

Исхаков, Ф. Г., Пальмбах, А. А. (1961) Грамматика тувинского языка. Фонетика и морфология / отв. ред. Е. И. Убрятова. М. : Восточная литература. 472 с.

Кара-оол, Л. С. (2006) Термины родства и свойства в тувинском языке. Кызыл : РИО ТывГУ. 252 с.

Кара-оол, Л. С. (2007) Лексика традиционного свадебного обряда в тувинском языке // Казань и алтайская цивилизация. 50-я ежегодная международная научная алтаистическая конференция г. Казань, 1-6 июля 2007 г.: Труды и материалы / под общ. ред. З. Г. Нигматова . Казань : Идел-пресс. 264 с. С. 99-101.

Кара-оол, Л. С. (2008) Тувинская семья // Российская семья: энциклопедия / гл. научный ред. В. И. Жуков. М. : Издательство РГСУ. 624 с. С. 443-456.

Кара-оол, Л. С. (2015) Лексика предсвадебных обрядов в тувинском языке // Урало-алтайские исследования. № 4 (19). С. 17-31.

Карпухин, И. Е. (2011) Свадьбы в Башкортостане на стыке тысячелетий : (состояние, поэтика, межэтнические контакты) / отв. ред. В. А. Беглов. Уфа : Китап. 544 с.

Кенин-Лопсан, М. Б. (1994) Тыва чоннуң бурунгу ужурлары [Традиционная этика тувинцев]. Кызыл : Новости Тувы. 192 с. (На тув. яз.).

Кенин-Лопсан, М. Б. (2006) Традиционная культура тувинцев. Кызыл : Тувинское книжное издательство. 232 с.

Кон, Ф. Я. (1934) За пятьдесят лет: Собрание сочинений: в 3 т. М. : Изд-во Всесоюз. о-ва политкаторжан и ссыльно-поселенцев ; тип. Профиздата. Т. 3. Экспедиция в Сойотию. 293 с.

Кунаа, А. Ч. (1957) Звуковая система современного тувинского языка / ред. Ш. Ч. Сат. Кызыл : Типография управления культуры. 56 с.

Куулар, Х., Куулар, Ө., Куулар, Д.-Д., Куулар, Л.-Д. (2014) Хам болгаш делегей [Шаман и мир]. Кызыл : Тип. КцО «Аныяк». 132 с.

Кушкаш, Т. (1996) Тожунуң бурунгузу [Древние традиции Тоджи]. Кызыл : Эне сөзү. С. 23-25.

Ламажаа, Ч. К., Майны, Ш. Б. (2020) Свадебная обрядность тувинцев: от установления семейных связей до социальной презентации // Oriental Studies. T. 13. № 2. С. 405-421. DOI: https://doi.org/10.22162/2619-0990-202048-2-405-421

Монгуш, М. В. (2002) Тувинцы Монголии и Китая. Этнодисперсные группы (История и современность). Новосибирск : Наука. 128 с.

Потапов, Л. П. (1969) Очерки народного быта тувинцев / отв. ред. А. П. Окладников. М. : Наука. 402 с.

Рассадин, В. И. (1971) Фонетика и лексика тофаларского языка / отв. ред. Ц. Б. Цыдендамбаев. Улан-Удэ : Бурятское книжное издательство. 252 с.

Рассадин, В. И. (1995) Тофаларско-русский словарь. Русско-тофаларский словарь / отв. ред. И. Д. Бураев. Иркутск : Восточно-Сибирское книжное издательство. 288 с. 
Севортян, Э. В. (1974) Этимологический словарь тюркских языков: общетюркские и межтюркские основы на гласные / ред. Р. М. Залесковская. М. : Наука. 768 с.

Севортян, Э. В. (1978) Этимологический словарь тюркских языков: общетюркские и межтюркские основы на букву “Б” / отв. ред. Н. З. Гаджиева. М. : Наука. 352 с.

Севортян, Э. В. (1980) Этимологический словарь тюркских языков: общетюркские и межтюркские основы на буквы “В”, “Г”, “Д” / отв. ред. Н. З. Гаджиева. М. : Наука. 390 с.

Серен, П. (2000) Моолда тываларның чаңчылдары (орук демдектери). [Традиции тувинцев Монголии (путевые заметки)]. Кызыл : Тип УПО «Аныяк». 58 с. (На тув. яз.)

Серен, П. (2006) Моолда сенгел тываларының чаңчылдары (дылының, культуразының материалдары) [Обычаи цэнгэльских тувинцев в Монголии (материалы языка, культуры)]. Кызыл : Респ. тип-я. 104 с. (На тув. яз.).

Серен, П. (2013а) Моолда цагаан-нуур тываларының ёзу-чаңчылдары: дылының, культуразының материалдары [Обряды и обычаи цагаан-нурских тувинцев в Монголии: материалы языка, культуры]. Кызыл : ОАО «Тываполиграф». 192 с.

Серен, П. (2013b) Моолда хомду тываларының ёзулалдары [Обычаи ховдских тувинцев Монголии]. Кызыл : ОАО «Тываполиграф». 160 с.

Сравнительно-историческая грамматика тюркских языков. Лексика (2001) / отв. ред. Э. Р. Тенишев М. : Наука. 824 c.

Татаринцев, Б. И. (2000) Этимологический словарь тувинского языка. Новосибирск : Наука. Т. І. А-Б. 341 с.

Татаринцев, Б. И. (2002) Этимологический словарь тувинского языка. Новосибирск : Наука. Т. II. Д-Й. 388 с.

Татаринцев, Б. И. (2004) Этимологический словарь тувинского языка. Новосибирск : Наука. Т. III. К-Л. 440 с.

Татаринцев, Б. И. (2008) Этимологический словарь тувинского языка. Новосибирск : Наука. Т. IV. M-П. 442 с.

Тувинско-русский словарь (1968) : 22000 слов / ред. Э. Р. Тенишев. М. : Советская энциклопедия. 648 с.

Толковый словарь тувинского языка (2003) / ред. Д. А. Монгуш. Новосибирск : Наука. Т. І: А-Й. 599 с.

Толковый словарь тувинского языка (2011) / ред. Д. А. Монгуш. Новосибирск : Наука. Т. II: К-С. 798 с.

Уламсурейн, Ц. (2003) Образцы фольклора и речи кобдоских тувинцев. Кызыл : Тувинское книжное издательство. 192 с.

Хертек, Я. Ш. (1975) Тувинско-русский фразеологический словарь. Кызыл : Тувинское книжное издательство. 206 c.

Хертек, Л. К. (2007) Символика мифологических образов в обрядах перехода у тувинцев // Мир науки, культуры, образования. № 4 (7). С. 68-72.

Хертек, Л. К. (2008) Устойчивые формулы и терминология свадебной обрядности тувинцев // Эртем бижиктери (Учёные записки) / отв. ред. М. В. Бавуу-Сюрюн. Кызыл : ТывГУ. Вып. II. 174 с. С. 80-91.

Этимологический словарь тюркских языков (2000): общетюркские и межтюркские основы на букву “К” / отв. ред. Г. Ф. Благова. М. : Индрик. Вып. 2. 265 с.

Этимологический словарь тюркских языков (2003): общетюркские и межтюркские лексические основы на буквы “Л”, “М”, “Н”, “П”, “С” / отв. ред. А. В. Дыбо. М. : Восточная литература. 446 с.

Яковлев, Е.К. (1900) Семейный и общественный быт у сойот: роды, степени родства, брак и положение женщины, развод, население, похороны // Яковлев, Е. К. Этнографический обзоръ инородческаго населенія долины Южного Енисея и объяснительный каталогъ этнографическаго отдьла музея. Минусинск : Типография В. И. Корнакова. Вып. 4.341 с. С. 79-99.

Rassadin, V. I. (2010) Soyotica / ed. by B. Kempf. Szeged : Univ., Dep. of Altaic Studies. 230 p.

Submission date: 20.10.2020 2.

\section{REFERENCES}

Aiyzhy, E. V (2005) Svadebnaia obriadnost' tuvintsev Kobdoskogo aimaka Mongolii [Wedding rites of Tuvans of the Kobdo aimag of Mongolia]. In: Prirodnye usloviia, istorii i kul'tury Zapadnoi Mongolii i sopredel'nykh regionov [Natural conditions, history and culture of Western Mongolia and neighboring regions]: proceedings of the $7^{\text {th }}$ International conference (September 19-23, 2005, Kyzyl): in 2 vols. / ed. by V. I. Lebedev, S. O. Ondar and Yu. G. Poluliakh. Kyzyl, TuvIKOPR SO RAN. Vol. 2. 252 p. Pp. 16-20. (In Russ.).

Biche-ool, S. M. (1974) Traditsionnye brachno-semeinye otnosheniia u tuvintsev i ikh izmeneniia v sviazi s sotsialisticheskimi preobrazovaniiami $v$ Tuve [Traditional marriage and family relations among Tuvans and changes in these brought about by Socialist transformations in Tuva] : Abstract of Diss... Candidate of History. Leningrad. 20 p. (In Russ.).

Bol'shoi akademicheskii mongol'sko-russkii slovar' [The Large Academic Mongolian-Russian Dictionary] (2001a): in 4 vols. / executive editor G. Ts. Piurbeev. Moscow, Academia. Vol. 1. 520 p. (In Russ.) 
Bol'shoi akademicheskii mongol'sko-russkii slovar' [The Large Academic Mongolian-Russian Dictionary] (2001b): in 4 vols. / executive editor G. Ts. Piurbeev. Moscow, Academia. Vol. 2. 536 p. (In Russ.)

Bol'shoi akademicheskii mongol'sko-russkii slovar' [The Large Academic Mongolian-Russian Dictionary] (2001c): in 4 vols. / executive editor G. Ts. Piurbeev. Moscow, Academia. Vol. 3. 440 p. (In Russ.)

Bol'shoi akademicheskii mongol'sko-russkii slovar' [Large academic Mongolian-Russian dictionary] (2002): in 4 vols. / executive editor. G. Ts. Piurbeev. Moscow, Academia. Vol. 4. 532 p. (In Russ.)

Vainshtein, S. I. (1961) Tuvintsy-todzhintsy. Istoriko-etnograficheskie ocherki [Tozhu tuvans: historical and ethnographic essays]. Moscow, Nauka. 218 p. (In Russ.).

Grum-Grzhimailo, G. E. (1926) Zapadnaya Mongoliya i Uryanhaiskii krai [Western Mongolia and the Uriankhai Territory]. Vol. 3. Part 1. An anthropological and ethnographical sketch of these countries by G. Grum-Grzhimailo. Leningrad, State (Russian) Geographical Society. 412 p. (In Russ.).

Dongak, S. Ch. (2012) Tyva kuda ezulaldary = Traditsii tuvinskoi svad'by [The tradition of Tuvan wedding]. Kyzyl, TuvGU Publ. 72 p. (In Tuv. and Russ.)

Drevnetiurkskii slovar' [An old Turkic dictionary] (1969) / ed. by V. M. Nadeljaev, D. M. Nasilov, E. R. Tenishev and A. M. Shcherbak. Leningrad, Nauka. 679 p. (In Russ.).

Iskhakov, Ph. G. and Pal'mbakh, A. A. (1961) Grammatika tuvinskogo iazyka. Fonetika i morfologiia [A grammar of the Tuvan language. Phonetics and morphology]. Moscow, Vostochnaia literature Publ. 472 p. (In Russ.).

Kara-ool, L. S. (2006) Terminy rodstva i svoistva $v$ tuvinskom yazyke [Kinship and in-law terms in the Tuvan language]. Kyzyl, Tuvan State University. 252 p. (In Russ.).

Kara-ool, L. S. (2007) Leksika traditsionnogo svadebnogo obriada v tuvinskom iazyke [Vocabulary of the traditional wedding ceremony in the Tuvan language]. In: Kazan' $i$ altaiskaia tsivilizatsiia [Kazan and the Altai civilization]. 50th annual international scientific altaistic conference Kazan, July 1-6, 2007: Proceedings and materials / ed. by Z. G. Nigmatov. Kazan', Idel-press. 264 p. Pp. 99-101. (In Russ.).

Kara-ool, L. S. (2008) Tuvinskaia sem'ia [Tuvan family]. In: Rossiiskaia sem'ia [Russian family]: an encyclopedia / ed. by V. I. Zhukov. Moscow, RGSU Publ. 624 p. Pp. 443-456. (In Russ.).

Kara-ool L. S. (2015) Leksika predsvadebnykh obriadov v tuvinskom iazyke [Lexicon of pre-wedding rituals in Tuvan]. Uralo-altaiskie issledovaniia, no. 4 (19), pp. 17-31. (In Russ.).

Karpukhin, I. E. (2011) Svad'by v Bashkortostane na styke tysiacheletii : (sostoianie, poetika, mezhetnicheskie kontakty) [Weddings in Bashkortostan at the turn of the 3rd millennium : current state of affairs, poetics, interethnic contacts] / ed. by V. A. Beglov. Ufa, Kitap. 544 p. (In Russ.).

Kenin-Lopsan, M. B. (1994) Туva chonnuњ burungu uzhurlary [Traditional ethics of Tuvans]. Kyzyl, Novosti Tuvy. 192 p. (In Tuv.).

Kenin-Lopsan, M. B. (2006) Traditsionnaia kul'tura tuvintsev [Traditional culture of Tuvans]. Kyzyl, Tuvan book publisher. 232 p. (In Russ.).

Kon, F. Ya. (1934) Ekspeditsiia v Soiotiiu [An Expedition to Soyotia]. Za piat'desiat let [In fifty years]: in 3 vols. Moscow, Izdatel'stvo Vsesoiuznogo obshchestva politkatorzhan i ssyl'no-pereselentsev. Vol. 3. 296 p. (In Russ.).

Kunaa, A. Ch. (1957) Zvukovaia sistema sovremennogo tuvinskogo iazyka [The sound system of the modern Tuvan language]. Kyzyl, Tuvan book publisher. 53 p. (In Russ.)

Kuular, Kh., Kuular, Ö., Kuular, D.-D. and Kuular, L.-D. (2014) Kham bolgash delegei [Shaman and the world]. Kyzyl, Tip. KTsO «Anyiak». 132 p. (In Tuv.).

Kushkash, T. (1996) Тоzhunuң burunguzu [The ancient traditions of Tozhu Tuvans]. Kyzyl, Ene sözü. Pp. 23-25. (In Tuv.).

Lamazhaa, Ch. K. and Mainy, Sh. B. (2020) Svadebnaia obriadnost' tuvintsev: ot ustanovleniia semeinykh sviazei do sotsial'noi prezentatsii [Tuvan Wedding Rites: from Establishment of Family Ties to Social Presentation]. Oriental Studies, vol. 13, no. 2, pp. 405-421. (In Russ.). DOI: https://doi.org/10.22162/2619-0990-2020-48-2-405-421

Mongush, M. V. (2002) Tuvintsy Mongolii i Kitaia. Etnodispersnye gruppy (Istoriia i sovremennost') [Tuvans of Mongolia and China. Diaspora groups: history and modernity]. Novosibirsk, Nauka. 128 p. (In Russ.).

Potapov, L. P. (1969) Ocherki narodnogo byta tuvintsev [The Tuvans: sketches of the folk lifestyle and related household activities]. Moscow, Nauka, GRVL. 402 p. (In Russ.).

Rassadin, V. I. (1971) Fonetika i leksika tofalarskogo iazyka [Phonetics and lexics of Tofalar language]. Ulan-Ude, Buriatskoe knizhnoe izdatel'stvo. 252 p. (In Russ.).

Rassadin V. I. (1995) Tofalarsko-russkii slovar'. Russko-tofalarskii slovar' [A Tofalar-Russian and Russian-Tofalar dictionary] / ed. by I. D. Buraev. Irkutsk, Vostochno-Sibirskoe knizhnoe izdatel'stvo. 288 p. (In Russ.). 
Sevortian, E. V. (1974) Etimologicheskii slovar' tiurkskikh iazykov: obshchetiurkskie i mezhtiurkskie osnovy na glasnye [An etymological dictionary of Turkic languages: common Turkic and inter-Turkic vowel bases] / ed. by R. M. Zaleskovskaia. Moscow, Nauka. 768 p. (In Russ.).

Sevortian E. V. (1978) Etimologicheskii slovar' tiurkskikh iazykov: obshchetiurkskie i mezhtiurkskie osnovy na bukvu " $B$ " [An etymological dictionary of Turkic languages: common Turkic and inter-Turkic bases with the letter " $B$ "] / ed. by N. Z. Gadzhieva. Moscow, Nauka. 352 p. (In Russ.).

Sevortian E. V. (1980) Etimologicheskii slovar' tiurkskikh iazykov: obshchetiurkskie i mezhtiurkskie osnovy na bukvy " $V$ ", “G”, “ $D$ ” [An etymological dictionary of Turkic languages: common Turkic and inter-Turkic bases on the letters “ $B$ ”, “ $G$ ”, “ $D$ ”] ed. by N. Z. Gadzhieva. Moscow, Nauka. 390 p. (In Russ.).

Seren, P. (2000) Moolda tyvalarnyњ chaßchyldary (oruk demdekteri). [Traditions of the Tuvans of Mongolia: travel notes)]. Kyzyl, Tip UPO «Anyiak». 58 p. (In Tuv.)

Seren, P. (2006) Moolda sengel tyvalarynyњ chaßchyldary (dylynyњ, kul'turazynyњ materialdary) [Customs of Tsengel Tuvans in Mongolia: materials of language and culture]. Kyzyl, Resp. tip-ia. 104 p. (In Tuv.).

Seren, P. (2013a Moolda tsagaan-nuur tyvalarynyњ еzu-chaßchyldary: dylyny,, kul'turazynyњ materialdary [Rituals and customs of Tsagaan-Nur Tuvans in Mongolia: materials of language and culture]. Kyzyl, OAO «Tyvapoligraf». 192 p. (In Tuv.).

Seren P. (2013b) Moolda khomdu tyvalarynym ezulaldary [Customs of the Khovd Tuvans of Mongolia]. Kyzyl, OAO «Tyvapoligraf». 160 p. (In Tuv.).

Sravnitel'no-istoricheskaia grammatika tiurkskikh iazykov. Leksika [A comparative historical grammar of Turkic languages: Vocabulary] (2001) / ed. by E. R. Tenishev. Moscow, Nauka Publ. 800 p. (In Russ.).

Tatarintsev, B. I. (2000) Etimologicheskii slovar' tuvinskogo iazyka [An etymological dictionary of the Tuvan language]. Novosibirsk, Nauka. Vol. I: A-B. 339 p. (In Russ.)

Tatarintsev, B. I. (2002) Etimologicheskii slovar' tuvinskogo iazyka [An etymological dictionary of the Tuvan language]. Novosibirsk, Nauka. Vol. II. D-I. 388 p. (In Russ.)

Tatarintsev, B. I. (2004) Etimologicheskii slovar' tuvinskogo iazyka [An etymological dictionary of the Tuvan language]. Novosibirsk, Nauka. Vol. III. K-L. 440 p. (In Russ.)

Tatarintsev B. I. (2008) Etimologicheskii slovar' tuvinskogo iazyka [An etymological dictionary of the Tuvan language]. Novosibirsk, Nauka. Vol. IV. M-P. 442 p. (In Russ.)

Tuvinsko-russkii slovar' [A Tuvan-Russian Dictionary] (1968): c. 22000 words / ed. by E. R. Tenishev. Moscow, Sovetskaia entsiklopediia. 465 p. (In Russ. and Tuv.).

Tolkovyi slovar' tuvinskogo yazyka [An explanatory dictionary of the Tuvan language] (2003) / ed. by D. A. Mongush. Novosibirsk, Nauka. Vol. 1.597 p. (In Russ. and Tuv.).

Tolkovyi slovar' tuvinskogo iazyka [An explanatory dictionary of the Tuvan language] (2011) / ed. by D. A. Mongush. Novosibirsk, Nauka Publ. Vol. II. K-C. 798 p. (In Russ. and Tuv.)

Tsetsegdar', U. (2003) Obraztsy fol'klora i rechi Kobdoskikh tuvintsev [Samples of folklore and speech of the Kobdo Tuvans]. Kyzyl, Tuva book publishing house. 191 p. (In Russ.)

Khertek, Ya. Sh. (1975) Tuvinsko-russkii frazeologicheskii slovar' [A Tuvan-Russian phraseological dictionary]. Kyzyl, Tuva book publishing house. 206 p. (In Russ.)

Khertek, L. K. (2007) Simvolika mifologicheskikh obrazov v obriadakh perekhoda u tuvintsev [Symbolism of mythological images in the rites of passage among the Tuvans]. Mir nauki, kul'tury, obrazovaniia, no. 4 (7), pp. 68-72. (In Russ.)

Khertek, L. K. (2008) Ustoichivye formuly i terminologiia svadebnoi obriadnosti tuvintsev [Stable formulas and terminology of Tuvinian wedding rites]. In: Ertem bizhikteri (Uchenye zapiski) / ed. by M. V. Bavuu-Surun. Kyzyl,TyvGU. Vol. II. 174 p. Pp. 80-91. (In Russ.)

Etimologicheskii slovar' tiurkskikh iazykov [Etymological dictionary of Turkic languages] (2000): common Turkic and interTurkic bases with the letter "K” / ed. by G. F. Blagova. Moscow, Indrik. Vol. 2. 265 p. (In Russ.)

Etimologicheskii slovar' tiurkskikh iazykov [Etymological dictionary of Turkic languages] (2003): common Turkic and interTurkic bases with the letter "L", “M”, “N”, “P”, “S” / ed. by A. V. Dybo. Moscow, Vostochnaia literatura. 446 p. (In Russ.)

Yakovlev, E. K. (1900) Semeinyi i obshchestvennyi byt u soiot: rody, stepeni rodstva, brak i polozhenie zhenshchiny, razvod, naselenie, pokhorony [Family and social life of the Soyot: birth, degree of kinship, marriage and status of women, divorce, population and funeral]. In: Yakovlev, E. K. Etnograficheskii obzor inorodcheskogo naseleniya doliny Yuzhnogo Eniseya i ob"yasnitel'nyi katalog Etnograficheskogo otdela Muzeya [An ethnographic review of the South Yenisei Valley and the explanatory catalogue of the Museum's Ethnography Research Department]. Minusinsk, V. I. Kornakov. 357 p. Pp. 79-99. (In Russ.).

Rassadin, V. I. (2010) Soyotica / ed. by B. Kempf. Szeged, Univ., Dep. of Altaic Studies. 230 p.

Submission date: 20.10 .2020 . 